\title{
Efektivitas Model Pembelajaran Auditory Intellectualy Repetition Dipadu Media Video terhadap Minat Belajar Siswa
}

\author{
Agung Ramadhan ${ }^{1}$, Tien Aminatun ${ }^{1}$ \\ Pendidikan Biologi-Universitas Negeri Yogyakarta
}

\section{INFO ARTIKEL}

\section{Riwayat Artikel:}

Diterima: 06-01-2019

Disetujui: 20-03-2019

Kata kunci:
effectiveness;
auditory intellectualy repetition;
video media;
interest to learn;
efektivitas;
auditory intellectualy repetition;
media video;
minat belajar

\section{Alamat Korespondensi:}

Agung Ramadhan

Pendidikan Biologi

Universitas Negeri Yogyakarta

Jalan Colombo No.1 Kec. Depok, Kab. Sleman, Daerah Istimewa Yogyakarta

E-mail: agung018.ar@gmail.com

\begin{abstract}
The purpose of this study was to determine the effectiveness of the AIR (Auditory, Intellectualy Reppetition) model combined video media on the interest in learning of Banguntapan 2 High School students. This type of research is quantitative descriptive research and research desaign using the design group control pretestposttest. The method used is a quasi-experimental method, the data collection technique used is a non-test technique (questionnaire). The result of the study based on the learning interest questionnaire given to students showed that the AIR model combined video media is effective to increase students' interest in learning, was based on the result of data analysis which showed that there were significant differences between students given learning with conventional models and students given learning with the AIR model combined video media.
\end{abstract}

\begin{abstract}
Abstrak: Tujuan penelitian ini untuk mengetahui efektivitas model AIR (Auditory Intellectualy Repetition) dipadu media video terhadap minat belajar siswa SMA N 2 Banguntapan. Jenis penelitian ini adalah penelitian deskriptif kuantitatif dan desain penelitian menggunakan pretest-posttest control grup design. Metode yang digunakan adalah metode eksperimen semu (quasi eksperimen), teknik pengumpulan data yang digunakan adalah teknik non tes (angket). Hasil penelitian berdasarkan angket minat belajar yang diberikan kepada siswa menunjukkan bahwa model AIR dipadu media video efektif untuk meningkatkan minat belajar siswa, hal tersebut didasari oleh hasil analisis data yang menunjukan terdapat perbedaan yang signifikan antara siswa yang diberikan pembelajaran dengan model konvensional dan siswa yang diberikan pembelajaran dengan model AIR dipadu media video.
\end{abstract}

Pembelajaran adalah suatu proses interaksi yang terjadi antar sesama peserta didik, antara peserta didik dengan pendidik, dan antara peserta didik dengan sumber belajar pada suatu lingkungan belajar (PP No. 32 Tahun 2013 pasal 1 ayat 19). Dari peraturan pemerintah tersebut dapat disimpulkan bahwa pembelajaran merupakan suatu proses interaksi 2 arah sehingga pembelajaran seharusnya merupakan kegiatan yang tidak hanya berpusat pada guru, tetapi kepada siswa, tidak monoton, membuat siswa senang dalam melakukan pembelajaran sehingga siswa memiliki minat dalam melakukan kegiatan pembelajaran dan tujuan pembelajaran dapat tercapai. PP No. 32 Tahun 2013 pasal 19 ayat 1 menyatakan bahwa proses pembelajaran dilakukan secara interaktif, inspiratif, menyenangkan, menantang, memotivasi siswa untuk berpartisipasi aktif, serta memberikan ruang yang cukup bagi prakarsa, kreativitas, dan kemandirian sesuai dengan bakat, minat, dan perkembangan fisik serta psikologis siswa.

Berdasarkan hasil wawancara yang telah dilakukan peneliti dengan guru mata pelajaran Biologi di SMAN 2 Banguntapan diketahui bahwa pembelajaran yang dilakukan di sekolah khususnya materi ekologi masih belum efisien, dikarenakan saat guru memberikan tugas kepada siswa untuk mengamati lingkungan di sekitar sekolah siswa tidak bersungguhsungguh untuk menyelesaikan tugas tersebut sehingga tujuan pembelajaran tidak terpenuhi. Menurut guru mata pelajaran, siswa belum ada minat dan tanggung jawab dalam melaksanakan tugasnya apabila diberikan tugas tanpa pengawasan, sehingga guru kebanyakan melakukan pembelajaran di dalam kelas dengan model yang monoton seperti diskusi dan ceramah. Selanjutnya guru menuturkan bahwa hasil belajar yang diperoleh siswa saat pembelajaran ekologi di dalam kelas kurang bagus dibandingkan saat pembelajaran ekologi di luar kelas, namun kendala saat pembelajaran di luar kelas seperti yang telah 
dijelaskan sebelumnya, yaitu siswa tidak bersungguh-sungguh dalam melaksanakan tugas yang diberikan, memakan waktu dan tenaga karena harus mengoordinir semua siswa yang terpisah letak pemberian tugasnya, yaitu di sekitar sekolah. Sehingga menurut guru, pembelajaran diluar kelas kurang efisien. Menurut Sudjana \& Rivai (2017), bahwa pelaksanaan pembelajaran di luar kelas memiliki kelemahan yang sering terjadi yang pertama yaitu apabila kegiatan pembelajaran di luar kelas kurang dipersiapkan dengan baik, maka akan menyebabkan siswa tidak melakukan kegiatan belajar yang diharapkan sehingga menyebabkan kesan main-main. Kedua, kegiatan yang mempelajari lingkungan memerlukan waktu yang cukup lama.

Dari hasil wawancara tersebut, peneliti menggunakan model pembelajaran AIR dipadu media video untuk proses pembelajaran di dalam kelas karena sifatnya yang tidak kaku, berpusat pada siswa, menyenangkan, siswa diperlihatkan secara langsung keadaan lingkungan melalui media video seperti pengamatan langsung ( real object), siswa diperlihatkan kejadian dan proses yang tidak bisa diamati secara langsung oleh mata, siswa diperlihatkan benda-benda yang tidak bisa di hadirkan di dalam kelas karena sifatnya yang berbahaya seperti hewan buas dan sifatnya yang terlalu besar seperti hutan. Media video dapat mengatasi masalah letak geografis seperti apabila seseorang yang tinggal di daerah pegunungan yang ingin melihat pantai dapat menggunakan media video (Nuryani, 2005). Sehingga dari penggunaan model pembelajaran AIR dipadu media video ini dapat menggantikan pembelajaran di luar kelas yang kurang efisien, namun dapat meningkatkan minat belajar.

Model AIR (Auditory Intellectually Repetition) merupakan salah satu model pembelajaran yang inovatif dalam menstimulus minat belajar siswa. Belajar dengan menggunakan auditory merupakan belajar yang mengandalkan indra pengucapan dan pendengaran (Shoimin, 2017) (Huda, 2013) (Meier, 2002). Belajar dengan intellectually menandakan bahwa belajar harus mengandalkan kemampuan berpikir, terus berlatih menggunakannya dengan cara menalar, mengidentifikasi mencipta, mengonstruksi dan menerapkan (Shoimin, 2017). Sedangkan belajar dengan repetition bermakna pengulangan dalam belajar, sehingga apa yang telah dipelajari dapat diulangi, diperluas, dan pemantapan, caranya dengan memberikan kuis atau tugas menyangkut pembelajaran yang telah dipelajari (Huda, 2013). Model AIR memiliki beberapa kelebihan dan kelemahan, kelebihan model AIR yaitu peserta didik lebih berpartisipasi aktif, memiliki kesempatan lebih banyak dalam mememanfaatkan pengetahuan, peserta didik termotivasi dalam memberikan penjelasan, dan peserta didik memiliki banyak pengalaman (Shoimin, 2017). Sedangkan kelemahannya yaitu, peserta didik kesulitan memahami permasalahan yang diberikan guru, guru kesulitan dalam mempersiapkan permasalahan yang bermakna untuk dibahas bersama peserta didik, dan peserta didik dapat memiliki keraguan dalam memberikan jawaban mereka sendiri (Shoimin, 2017).

Menurut Rizkiardi \& Subali (2018), bahwa model AIR dapat berdampak untuk merubah minat belajar siswa. Menurut Suharyat (2009), bahwa minat terbagi atas 2 pengertian, pertama, usaha dan kemauan untuk belajar dan mencari sesuatu, kedua, dorongan individu dalam mencapai suatu tujuan. Selanjutnya Daskalovska, Koleva, \& Ivanovska (2012), bahwa pengajar harus berusaha untuk membangkitkan minat belajar dengan cara memberikan hiburan seperti lelucon, film, video klip, serta menggunakan penglihatan. Sehingga minat seseorang dapat dipicu oleh rangsangan visual seperti melihat gambar, rangsangan auditory seperti mendengar percakapan, atau kombinasi antar keduanya (Hidi, 2001).

Media dapat menstimulus keinginan, minat belajar, motivasi, dan merangsang kegiatan belajar peserta didik (Nuryani, 2005). Selanjutnya Wati (2016), mengemukakan bahwa media pembelajaran memiliki beberapa manfaat, diantaranya lebih menarik, materi pembelajaran akan lebih bermakna, dan siswa tidak mudah bosan. Media video memiliki kelebihan dan kelemahan, kelebihan media video yaitu dapat menarik perhatian peserta didik untuk periode yang singkat dan dapat menghemat waktu. Sedangkan kelemahannya yaitu, perhatian peserta didik sulit dipusatkan apabila mereka belum terbiasa dengan penggunaan media video dalam pembelajaran, media video bersifat satu arah sehingga guru harus mengimbangi dengan kegiatan lain yang dapat menimbulkan komunikasi dua arah, dan peralatan yang dibutuhkan untuk menghadirkan penggunaan media video dalam pembelajaran tergolong mahal (Wati, 2016).

Pengertian minat menurut Kamus Besar Bahasa Indonesia (2016), adalah kecenderungan hati individu yang besar terhadap sesuatu seperti gairah dan keinginan dalam melakukan aktivitas yang berhubungan dengan sesuatu yang diminati. Harackiewicz \& Hulleman (2010), mengemukakan bahwa minat terhadap sesuatu dapat menandakan kepedulian terhadap pentingnya suatu hal tersebut. Minat seseorang telah berulang kali diteliti dan terdapat pengaruh yang kuat terhadap pembelajaran seperti memengaruhi tujuan, perhatian, tingkat pembelajaran, komponen kognitif serta afektif (Hidi \& Harackiewicz, 2000) (Hidi \& Renninger, 2006). Suharyat (2009), mengemukakan bahwa minat merupakan peranan yang penting dalam kehidupan siswa sebagai sumber dari motivasi untuk belajar, sumber aspirasi, kegembiraan dan prestasi.

Jenis minat terbagi atas dua, yaitu minat intrinsik dan minat ekstrinsik (Li, Ge, Lian, \& Liu, 2015). Minat intrinsik merupakan minat yang keluar dari dalam diri individu yang disebabkan oleh kepentingan atau kemauan pribadi. Minat ekstrinsik merupakan minat yang keluar akibat dari pengaruh lingkungan individu (Katz, Assor, \& Kanat-maymon, 2006). Dari jenis minat tersebut, minat dapat dibagi menjadi tiga tipe, yaitu minat individu, minat situasional, dan minat topik (Hidi \& Renninger, 2006) (Ainley, Hidi, \& Berndorff, 2002), minat individu merupakan minat intrinsik sedangkan minat situasional dan minat topik merupakan minat ekstrinsik. 
Minat individu dapat didefinisikan sebagai minat terdalam pada suatu aktivitas yang timbul karena didasari oleh pengetahuan, emosi, pengalaman individu yang telah ada (Ainley et al., 2002). Minat individu lebih bertahan lama seperti sifat dan bertahan seiring waktu (Harackiewicz \& Hulleman, 2010). Minat situasional timbul secara spontan, bersifat sementara dan terikat secara situasional seperti reaksi yang timbul akibat melihat video klip yang menarik, percakapan yang menarik, atau objek yang menarik (Flowerday \& Shell, 2018) (Harackiewicz \& Hulleman, 2010). Selanjutnya Subramaniam (2009), mengemukakan bahwa minat situasional mengacu terhadap reaksi afektif yang dipicu saat itu oleh stimulus di lingkungan yang memiliki efek jangka pendek dan memengaruhi pengetahuan dan nilai individu. Minat topik adalah minat yang keluar akibat dari pemaparan suatu topik (Ainley et al., 2002). Sehingga dari tipe minat belajar diatas, dapat disimpulkan bahwa dalam penelitian ini minat situasionallah yang akan dimiliki oleh siswa, dan diharapkan minat situasional siswa akan terus berkembang sampai pada minat individu yang lebih bertahan lama. Indikator minat belajar dibagi menjadi empat aspek, yaitu perasaan senang (excitement), ketertarikan (interest), kebermaknaan (meaningfulness), dan keterlibatan (involvement) (Slameto, 2015). Berdasarkan latar belakang diatas, hipotesis penelitian ini yaitu model AIR (Auditory intellectually Repetition) dipadu media video efektif terhadap minat belajar siswa.

\section{METODE}

Jenis penelitian ini adalah eksperimen semu (Quasi eksperiment), dan teknik pengumpulan data yang digunakan berupa angket skala likert. Angket tersebut berisikan 26 pernyataan baik pernyataan positif dan pernyataan negatif yang telah divalidasi oleh dosen validator. Analisis data menggunakan uji prasyarat analisis dan uji hipotesis menggunakan aplikasi SPSS 16 for windows. Penelitian ini dilaksanakan di SMAN 2 Banguntapan Kabupaten Bantul Daerah Istimewa Yogyakarta. Populasi yang digunakan dalam penelitian ini adalah seluruh peserta didik SMAN 2 Banguntapan kelas X MIA semester genap yang terdiri dari empat kelas dengan jumlah peserta didik sebanyak 108 orang. Penentuaan sampel penelitian menggunakan teknik cluster random sampling.

Sampel penelitian yang terpilih dua kelas, yaitu kelas X MIA 3 dan kelas X MIA 4. Setelah sampel terpil ih, kemudian dilakukan pengundian untuk menentukan kelas yang dijadikan kelas eksperimen dan kelas kontrol. Kelas eksperimen diberikan perlakuan penelitian, yaitu digunakan model pembelajaran AIR dipadu media video dan untuk kelas kontrol digunakan model pembelajaran konvensional yang biasa digunakan guru mata pelajaran. Desain penelitian yang digunakan yaitu Pretest-Posttest Control-Group Design sehingga kedua kelas akan diberikan angket sebelum dan sesudah perlakuan. Subjek penelitian sebanyak 61 siswa kelas X MIA yang terdiri dari 32 siswa kelas X MIA 3 (kelas kontrol), dan 28 siswa kelas X MIA 4 (kelas eksperimen).

\section{HASIL}

Hasil penelitian diperoleh menggunakan analisis deskriptif, pemberian pretest dan posttest untuk mengetahui minat belajar siswa sebelum dan sesudah diberikan pembelajaran dengan model AIR dipadu media video. Pengukuran minat belajar dengan memberikan angket kepada siswa baik kelas kontrol maupun eksperimen. Hasil pengukuran minat belajar siswa disajikan pada tabel 1 .

Tabel 1. Rekapitulasi Data Hasil Minat Belajar Siswa Kelas Kontrol dan Eksperimen

\begin{tabular}{lcccc}
\hline \multirow{2}{*}{ Data } & \multicolumn{2}{c}{ Kelas Eksperimen } & \multicolumn{2}{c}{ Kelas Kontrol } \\
\cline { 2 - 5 } & Pretest & Posttest & Pretest & Posttest \\
\hline $\mathrm{N}$ & 28 & 28 & 32 & 32 \\
\hline Mean & 65.39 & 77.46 & 59.53 & 70.03 \\
\hline Standar Deviasi & 4.86 & 4.78 & 4.77 & 5.47 \\
\hline Nilai Minimum & 50 & 66 & 46 & 57 \\
\hline Nilai Maximum & 72 & 86 & 72 & 82 \\
\hline
\end{tabular}

Berdasarkan tabel diatas, deskripsi data yang disajikan berupa jumlah siswa (N), rata-rata (Mean), standar deviasi, nilai minimum dan nilai maximum. Nilai mean pretest kelas eksperimen sebesar 65.39 dan nilai mean posttest sebesar 77.46 , sedangkan nilai mean pretest kelas kontrol sebesar 59.53 dan nilai mean posttest sebesar 70.03. Berdasarkan deskripsi tersebut dapat disimpulkan bahwa terjadi peningkatan minat belajar pada kedua kelas. Berikut penyajian diagram rata-rata hasil analisis data nilai pretest dan posttest minat belajar siswa yang disajikan pada gambar 1. 


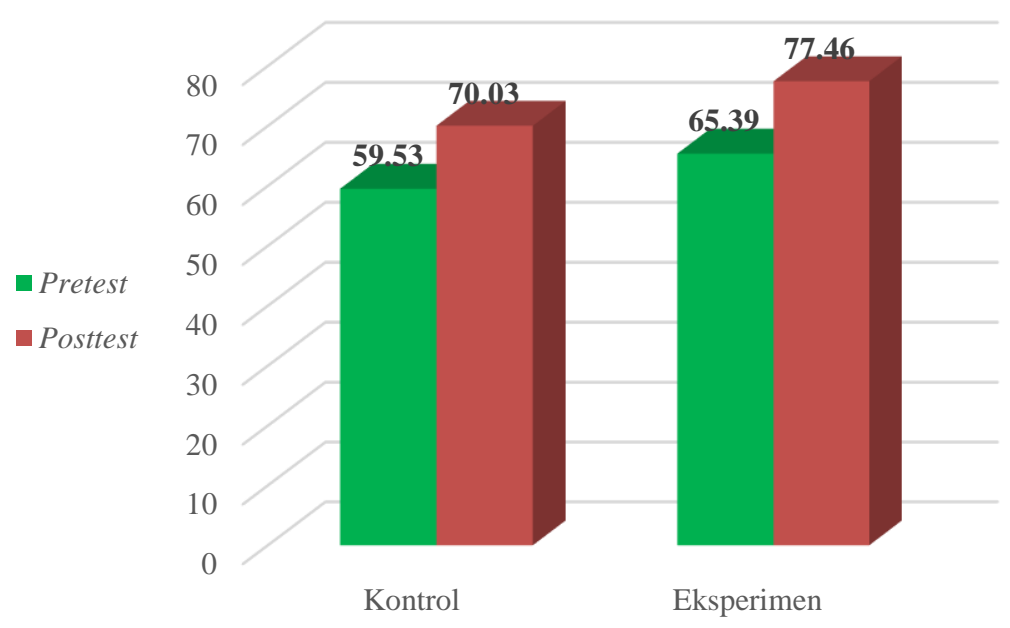

\section{Gambar 1. Diagram Batang Data Hasil Rata-rata Nilai Pretest dan Posttest Minat Belajar Siswa Kelas Kontrol dan Eksperimen}

\section{Pengujian Prasyarat Analisis}

Pengujian prasyarat dilakukan untuk mengetahui apakah data berdistribusi normal dan homogen atau tidak, uji prasyarat ini menggunakan data hasil pretest dan posttest siswa kelas kontrol dan eksperimen. Pengujian yang pertama dilakukan adalah uji normalitas yang menggunakan data hasil pretest dan posttest siswa, data dikatakan berdistribusi normal apabila nilai sig > 0.05, sebaliknya apabila nilai sig $<0.05$ maka data tidak berdistribusi normal. Dari hasil uji normalitas menggunakan bantuan SPSS, didapatkan hasil yang disajikan pada tabel 2.

Tabel 2. Hasil Uji Normalitas

\begin{tabular}{clcc}
\hline No & \multicolumn{1}{c}{ Data } & Signifikansi & Keterangan \\
\hline 1 & Pretest kelas kontrol & .111 & Nilai sig $>0.05=$ data berdistribusi normal \\
\hline 2 & Posttest kelas kontrol & .200 & Nilai sig $>0.05=$ data berdistribusi normal \\
\hline 3 & Pretest kelas eksperimen & .200 & Nilai sig $>0.05=$ data berdistribusi normal \\
\hline 4 & Posttest kelas eksperimen & .200 & Nilai sig $>0.05=$ data berdistribusi normal \\
\hline
\end{tabular}

Berdasarkan hasil uji normalitas diatas, dapat diketahui bahwa sebaran data minat belajar siswa berdistribusi normal karena nilai signifikansi lebih besar dari 0.05 sehingga data tersebut dapat dianalis lebih lanjut. Pengujian kedua yang dilakukan adalah uji homogenitas dengan menggunakan data hasil pretest dan posttest kelas kontrol dan eksperimen, uji homogenitas dilakukan untuk mengetahui kesamaan ragam kedua varians, data dikatakan homogen apabilai nilai sig >0.05. Begitupun sebaliknya, apabila nilai sig < 0.05 maka data tidak homogen. Berikut penyajian hasil uji homogenitas menggunakan bantuan SPSS yang disajikan pada tabel 3 .

Tabel 3. Hasil Uji Homogenitas

\begin{tabular}{ccccl}
\hline No & Data & Levene Statistik & Signifikansi & Keterangan \\
\hline 1 & Pretest & .016 & .901 & Homogen \\
\hline 2 & Posttest & .887 & .350 & Homogen \\
\hline
\end{tabular}

Berdasarkan hasil uji homogenitas diperoleh data pretest sebesar 0.901 dan posttest sebesar 0.350 kedua data di atas lebih besar dari 0.05 sehingga kedua sampel memiliki varians yang sama (homogen).

\section{Pengujian Hipotesis}

Pengujian hipotesis dilakukan untuk melihat apakah penerapan model AIR (Auditory Intellectualy Repetition) dipadu media video efektif terhadap peningkatan minat belajar siswa di SMA N 2 Banguntapan kab. Bantul Daerah Istimewa Yogyakarta pada materi ekologi. Analisis menggunakan uji independent sampel t-test pada program SPSS 16 for wondows. Hipotesis penelitian sebagai berikut: 
Ho : tidak ada perbedaan yang signifikan antara rata-rata nilai minat belajar siswa yang menggunakan model AIR (Auditory Intellectualy Repetition) dipadu media video dengan siswa yang tidak menggunakan model AIR (Auditory Intellectualy Repetition) dipadu media video.

$\mathrm{Ha}$ : ada perbedaan yang signifikan antara rata-rata nilai minat belajar siswa yang menggunakan model AIR (Auditory Intellectualy Repetition) dipadu media video dengan siswa yang tidak menggunakan model AIR (Auditory Intellectualy Repetition) dipadu media video.

Kriteria Ha diterima apabila nilai sig $<0.05$ yang artinya ada perbedaan yang signifikan antara kelas kontrol dan eksperimen. Berikut penyajian hasil uji-t minat belajar kelas kontrol dan eksperimen, ditunjukkan pada tabel 4 .

Tabel 4. Hasil Uji-t Data Posttest Minat Belajar

\begin{tabular}{cccc}
\hline Data & Sig.(2-tailed) & $\boldsymbol{a}$ & Keterangan \\
\hline Posttest & .000 & 0.05 & Berbeda Signifikan \\
\hline
\end{tabular}

Berdasarkan hasil Uji-t diatas diperoleh nilai sig.(2-tailed) sebesar $0.000<0.05$ sehingga dapat disimpulkan bahwa Ho ditolak dan Ha diterima yang artinya ada perbedaan yang signifikan antara rata-rata nilai minat belajar siswa yang mengikuti pembelajaran dengan model AIR (Auditory Intellectualy Repetition) dipadu media video dengan siswa yang tidak mengikuti pembelajaran dengan model AIR (Auditory Intellectualy Repetition) dipadu media video, yaitu mengikuti pembelajaran konvensional. Sehingga hal tersebut menandakan bahwa penerapan model pembelajaran AIR dipadu media video berpengaruh terhadap minat belajar siswa kelas X MIA SMA N 2 Banguntapan.

\section{Pengujian N-Gain}

Peningkatan minat belajar siswa kelas kontrol dan eksperimen diperoleh dengan menghitung nilai pretest dan posttest yaitu dengan uji N_Gain dengan bantuan program excel, dari analisis N_Gain akan diketahui seberapa besar peningkatan minat belajar siswa sebelum dan sesudah perlakuan. Berikut hasil perhitungan N_Gain yang disajikan pada tabel 5.

\section{Tabel 5. Hasil Uji N-Gain Kelas Kontrol dan Eksperimen}

\begin{tabular}{ccccc}
\hline Kelas & \multicolumn{4}{c}{ Nilai } \\
\cline { 2 - 5 } & $\mathbf{N}$ & Nilai Minimum & Nilai Maximum & Rata-rata \\
\hline Kontrol & 32 & 0.00 & 0.44 & 0.26 \\
\hline Eksperimen & 28 & 0.09 & 0.61 & 0.34 \\
\hline
\end{tabular}

Dari tabel di atas dapat diketahui perbedaan peningkatan rata-rata minat belajar siswa pada kelas kontrol sebesar 0.26 dan kelas eksperimen sebesar 0.34. Dari hasil tersebut peningkatan minat belajar kelas kontrol dikategorikan rendah, sedangkan kategori peningkatan kelas eksperimen sedang. Dari hasil uji N_Gain dengan bantuan program excel tersebut dapat diketahui bahwa peningkatan minat belajar siswa kelas eksperimen lebih tinggi dibandingkan kelas kontrol.

\section{PEMBAHASAN}

Penelitian ini dilaksanakan pada bulan Februari 2019 sampai bulan april 2019 di SMA N 2 Banguntapan Kabupaten Bantul. Tujuan dari pelaksanaan penelitian ini untuk mengetahui keefektivan model AIR (Auditory Intellectualy Repetition) dipadu media video terhadap minat belajar siswa pada materi ekologi kelas X semester genap. Sebelum melakukan penelitian, terlebih dahulu peneliti melakukan pra penelitian dimana kegiatan yang dilakukan adalah mewawancarai guru mata pelajaran biologi kelas x mengenai kegiatan pembelajaran di sekolah kemudian menyusun instrumen penelitian (silabus, RPP, LKS, dan lembar angket minat belajar. Setelah itu, instrumen penelitian di validasi oleh dosen ahli. Setelah dinyatakan valid, instrumen penelitian di pakai dalam penelitian. Seperti yang telah dijelaskan dalam metode penelitian, bahwa kelas kontrol merupakan kelas X MIA 3 yang mendapatkan perlakuan pembelajaran dengan model konvensional sedangkan kelas eksperimen merupakan kelas X MIA 4 yang mendapatkan perlakuan model AIR dipadu media video. Alokasi waktu penelitian pada masing-masing kelas adalah 9jp (3x pertemuan). Sebelum kelas diberikan perlakuan, terlebih dahulu kedua kelas diberikan pretest berupa angket minat belajar.

Pada saat pembelajaran, siswa yang berada di kelas kontrol diperlihatkan gambar mengenai materi yang akan dipelajari dan mereka diberikan pertanyaan "apa yang kalian pikirkan setelah melihat gambar tersebut", setelah itu siswa diperintahkan memberikan argumennya mengenai gambar tersebut. Untuk kelas eksperimen, siswa dibagi dalam beberapa kelompok dan diperlihatkan media video (Auditory) mengenai materi yang akan dipelajari pada hari itu, setelah mereka selesai mengamati video, mereka diberikan LKS pada masing-masing kelompok dan diperintahkan untuk menyelesaikan persoalan (Intellectually) yang terdapat di dalam LKS, persoalan yang teradapat dalam LKS tersebut berkaitan dengan video yang telah mereka amati sebelumnya (Repetition). Setelah mereka selesai mengerjakan LKS yang diberikan, mereka diperintahkan untuk memaparkan 
hasil diskusi kelompok mereka kepada kelompok lain dan kelompok lain diberikan kesempatan untuk menyanggah, memberikan pendapat, dan memberikan pertanyaan kepada kelompok penyaji. Pada akhir pertemuan kedua kelas diberikan posttest untuk mendapatkan data minat belajar siswa setelah diberikan perlakuan.

Berdasarkan hasil penelitian, keefektivan model AIR dipadu media video signifikan dalam meningkatkan minat belajar siswa yang dibuktikan dengan uji-t ditentukan dari perbandingan nilai rata-rata posttest minat belajar siswa terhadap materi ekologi. Hal tersebut dapat dilihat dari gambar diagram pada hasil penelitian diatas. Diagram tersebut juga menjelaskan bahwa nilai minat belajar siswa kelas kontrol dan eksperimen memiliki nilai yang berbeda yang dibuktikan dengan uji-t, dimana sig.(2tailed) data posttest adalah 0.000, hal tersebut menunjukan bahwa jika $\mathrm{p}<0.05$ sehingga nilai minat belajar tersebut berbeda signifikan. Untuk melihat peningkatan minat belajar siswa pada kelas kontrol dan eksperimen dilakukan dengan uji N_Gain , dari analisis N_Gain diperoleh data untuk kelas kontrol sebesar 0.26, sedangkan pada kelas eksperimen diperoleh data sebesar 0.34. Hasil tersebut menunjukkan bahwa peningkatan minat belajar kelas eksperimen lebih tinggi dibandingkan dengan kelas kontrol. Penelitian yang telah dilakukan oleh Arisanti \& Subhan (2018) Anam (2015), menyatakan bahwa penggunaan media dalam pembelajaran memberi pengaruh yang signifikan terhadap minat belajar siswa. Selanjutnya, penelitian yang dilakukan oleh Qomariah, Indriwati, \& Sulasmi (2013) menyatakan bahwa media pembelajaran dan minat belajar memengaruhi hasil belajar siswa. Dengan demikian, apabila siswa diberikan pembelajaran dengan menggunakan media dan siswa telah memiliki minat dalam belajar, hal tersebut akan memengaruhi hasil belajar siswa dalam artian akan menopang tercapainya tujuan pembelajaran.

Peningkatan minat belajar siswa disebabkan oleh penggunaan model pembelajaran AIR dipadu media video materi ekologi, materi tersebut digunakan dalam penelitian karena dari hasil wawancara dengan guru mata pelajaran Biologi, guru mengalami kesulitan dalam melakukan pembelajaran pada materi tersebut. Guru menginginkan agar siswanya melihat secara langsung mengenai materi ekologi, namun memiliki kendala pada pelaksanaannya dan hasil yang diperoleh, dimana pelaksanaan dan hasil yang diinginkan guru tidak terpenuhi. Sehingga penelitian ini menggunakan model AIR yang sifatnya mengasyikan dan tidak kaku, perpaduan dengan media video disebabkan karena model AIR memiliki kelemahan pada sintak Auditory (mendengar), dalam mendengar bisa saja terdapat kesalahan seperti kata three dan tree dalam bahasa Inggris, kedua kata ini berbeda maknanya, namun pengucapannya hampir sama sehingga orang yang hanya mendengar kata saja bisa keliru dalam memahami maknanya. Menurut Wati (2016) penyampaian informasi yang hanya mengandalkan bahasa verbal dapat menimbulkan verbalisme dan kesalahan persepsi. Oleh karena itu, penelitian ini memadukan media video agar kesalahan persepsi yang disebabkan oleh pendengaran dapat dikurangi dengan penglihatan.

\section{SIMPULAN}

Berdasarkan hasil penelitian yang telah dilakukan, maka dapat disimpulkan bahwa model AIR (Auditory, Intellectualy, Repetition) dipadu media video efektif untuk meningkatkan minat belajar siswa. Hal tersebut didasari oleh hasil analisis data yang menunjukkan terdapat perbedaan yang signifikan antara siswa yang diberikan pembelajaran dengan model konvensional dan siswa yang diberikan pembelajaran dengan model AIR dipadu media video karena pembelajaran dengan model AIR sifatnya mengasyikan dan tidak kaku seperti pembelajaran yang dilakukan di luar ruangan dan media video memperlihatkan secara langsung kepada siswa mengenai kejadian-kejadian yang terjadi menyangkut dengan materi ekologi dan isi dari media video tersebut merupakan kejadian yang biasa mereka amati dan alami di lingkungan sekitar mereka sehingga siswa tertarik untuk melakukan kegiatan pembelajaran dan diharapkan akan berdampak baik terhadap hasil belajar mereka.

\section{DAFTAR RUJUKAN}

Ainley, M., Hidi, S., \& Berndorff, D. (2002). Interest, Learning, and the Psychological Processes that Mediate their Relationship. Journal of Educational Psychology, 93(3), 545-561. https://doi.org/10.1037//0022-0663.94.3.545

Anam, K. (2015). Pengaruh Media Pembelajaran terhadap Minat Belajar Siswa pada Mata Pelajaran PAI di SMP Bani Muqiman Bangkalan. Tadarus: Jurnal Pendidikan Islam, 4(2). http://journal.um-surabaya.ac.id/index.php/Tadarus/article/view/984

Arisanti, D., \& Subhan, M. (2018). Pengaruh Penggunaan Media Internet terhadap Minat Belajar Siswa Muslim di SMP Kota Pekanbaru, 3(2), 61-73. https://doi.org/10.25299/althariqah.2018.vol3(2).2322

Daskalovska, N., Koleva, L., \& Ivanovska, B. (2012). Learner Motivation and Interest. Procedia - Social and Behavioral Sciences, 46, 1187-1191. https://doi.org/10.1016/j.sbspro.2012.05.272

Flowerday, T., \& Shell, D. F. (2018). Disentangling the Effects of Interest and Choice on Learning, Engagement, and Attitude Disentangling the Effects of Interest and Choice on Learning, Engagement, and Attitude. Learning and Individual Differences, 40 (May 2015), 134-140. https://doi.org/10.1016/j.lindif.2015.05.003

Harackiewicz, J. M., \& Hulleman, C. S. (2010). The Importance of Interest : The Role of Achievement Goals and Task Values in Promoting the Development of Interest. Social and Personality Psychology Compass, 4(1), 42-52. https://psych.wisc.edu/cmsdocuments/CompassHH.pdf 
Hidi, S. (2001). Interest, Reading, and Learning: Theoretical and Practical Considerations Author ( s ): Suzanne Hidi Published by : Springer Stable URL : https://www.jstor.org/stable/23363476 Interest, Reading, and Learning : Theoretical, 13(3), 191-209. https://www.jstor.org/stable/pdf/23363476.pdf?refreqid=excelsior\%3A79748b4662639cc7eb9637a7572a14de

Hidi, S., \& Harackiewicz, J. M. (2000). Motivating the Academically Unmotivated : A Critical Issue for the 21 st Century. Review of Educational Research, 70(2), 151-179. Retrieved from https://journals.sagepub.com/doi/10.3102/00346543070002151

Hidi, S., \& Renninger, K. A. (2006). The Four-Phase Model of Interest Development. Educational Psychologist, 41(2), 111127. Retrieved from https://www.academia.edu/27911093/The_Four Phase_Model_of_Interest_Development?auto=download

Huda, M. (2013). Model-model Pengajaran dan Pembelajaran. Yogyakarta: Pustaka Pelajar.

Katz, I., Assor, A. V. I., \& Kanat-maymon, Y. (2006). Interest as a motivational resource : Feedback and gender matter , but interest makes the difference. Social Psychology of Education, 9, 27-42. https://doi.org/10.1007/s11218-005-2863-7

Li, H., Ge, Y., Lian, D., \& Liu, H. (2015). Learning User' s Intrinsic and Extrinsic Interests for Point-of-Interest Recommendation: A Unified Approach. In Proceedings of the Twenty-Sixth International Joint Conference on Artificial Intelligence (IJCAI-17) (pp. 2117-2123). Retrieved from https://www.ijcai.org/proceedings/2017/0294.pdf

Nuryani, R. (2005). Strategi Belajar Mengajar Biologi. Malang: UM Press.

Peraturan Pemerintah No. 32 Tahun 2013 (2013). Tentang Perubahan Atas Peraturan Pemerintah, (19). https://kelembagaan.ristekdikti.go.id/wp-content/uploads/2016/08/PP0322013.pdf

Qomariah, L., Indriwati, S. E., \& Sulasmi, E. S. (2013). Penerapan Pembelajaran melalui Pendekatan Ilmiah untuk Meningkatkan Sikap, Pengetahuan, dan Keterampilan Proses Peserta Didik Kelas X MIA 4 SMAN 3 Malang pada Materi Kingdom. Jurnal Online UM Malang, 1-13.

Rizkiardi, reza M., \& Subali, B. (2018). Dampak Model Pembelajaran Auditory, Intellectually, Repetition (AIR) terhadap Minat Belajar, 12(1), 1-7. http://e-journal.upstegal.ac.id/index.php/Cakrawala/article/view/870/0

Shoimin, A. (2017). 68 Model Pembelajaran Inovatif dalam Kurikulum 2013. Yogyakarta: Ar-Ruzz Media.

Slameto. (2015). Belajar dan Faktor-faktor yang Memengaruhi. Jakarta: PT. Rineka Cipta.

Subramaniam, P. (2009). Motivational Effects of Interest on Student Engagement and Learning in Physical Education : A Review, 46(2), 11-20.

https://www.researchgate.net/publication/254971278_Motivational_Effects_of_Interest_on_Student_Engagement_and_L earning_in_Physical_Education_A_Review

Sudjana, N., \& Rivai, A. (2017). Media Pengajaran. Bandung: Sinar Baru Algensindo.

Suharyat, Y. (2009). Hubungan antara sikap, minat dan perilaku manusia. Region, 1(3), 1-19. Retrieved from https://www.academia.edu/25787317/Hubungan_Antara_Sikap_Minat_dan_Perilaku_Manusia

Wati, E. R. (2016). Ragam Media Pembelajaran. Yogyakarta: CV. Solusi Distribusi. 